\title{
Molecular diagnosis and risk factors of canine ehrlichiosis in the municipality of Itabuna-Bahia, Brazil
}

\section{Diagnóstico molecular e fatores de risco da erliquiose canina no município de Itabuna-Bahia}

\author{
Jeane Martinha dos Anjos Cordeiro우 Paula Elisa Brandão Guedes ${ }^{2}$; Alexandre Dias \\ Munhoz ${ }^{3}$; Fabiana Lessa Silva ${ }^{3 *}$
}

Highlights:

Dogs from Itabuna-Bahia have a high infection level by Ehrlichia canis.

Contact with other dogs is an important factor for the dissemination of ehrlichiosis.

Males had lower risk of infection with E. canis.

\begin{abstract}
Ehrlichiosis is an emerging zoonosis worldwide and has had several adverse effects on public health. Canine monocytic ehrlichiosis (CME), caused by Ehrlichia canis, has the tick Rhipicephalus sanguineus as the vector. The main clinical signs in affected dogs are fever, apathy, anorexia, weight loss, and neurological signs. The diagnosis is made through the association of clinical signs with parasitological, serological, and molecular tests. The aim of this study was to evaluate the occurrence of $E$. canis infection in dogs from the city of Itabuna-Bahia, as well as to identify the risk factors related to infection. For this, 405 dogs from the Center for Zoonoses Control (CCZ), non-governmental organizations (NGOs), and dogs domiciled and semi-domiciled in the city of Itabuna, southern Bahia, were evaluated. After initial physical evaluation of the dogs, blood samples were collected by venipuncture for subsequent DNA extraction and E. canis testing using the nested Polymerase Chain Reaction (nested-PCR) technique. In addition, an epidemiological questionnaire that included questions related to the animals was administered to the dog owners to identify the risk factors for exposure to the etiological agent and to the vector. Approximately $17 \%$ of the dogs in the municipality of Itabuna-Bahia tested positive for $E$. canis by nested-PCR, a result higher than that found in other studies conducted in the same municipality. Among the factors associated with E. canis infection, contact with other $\operatorname{dogs}(\mathrm{p}=0.0226)$ was an important factor for the dissemination of CME, since dogs are reported to be reservoirs of E. canis. Male dogs $(\mathrm{p}=0.0016)$ presented lower risk for $E$. canis infection. Other studies, however, describe no association between animal gender and infection by E. canis. Preventive measures to reduce exposure to the vector of ehrlichiosis are necessary.
\end{abstract}

Key words: Canis familiaris. Ehrlichia canis. Nested-PCR. Zoonosis. Vector-borne disease.

1 Discente de Doutorado, Curso de Pós-Graduação em Ciência Animal, Universidade Estadual de Santa Cruz, UESC, BA, Brasil. E-mail: jeane.martinha@gmail.com

2 Pós-Doutoranda PNPD, Programa de Pós-Graduação em Ciência Animal, UESC, BA, Brasil. E-mail: paulaebg@gmail.com

3 Prof ${ }^{\text {as. }}$ Pleno, Departamento de Ciências Agrárias e Ambientais, UESC, BA, Brasil. E-mail: munhoz@uesc.br; fabiana.lessa@ gmail.com

* Author for correspondence

Received: Mar. 29, 2019 - Approved: Aug. 07, 2019 


\section{Resumo}

A erliquiose é uma zoonose emergente em todo o mundo e tem acarretado diversos transtornos para a saúde pública. A erliquiose monocítica canina (EMC), causada pela Ehrlichia canis, tem como vetor o carrapato Rhipicephalus sanguineus. Os principais sinais clínicos nos cães afetados são febre, apatia, anorexia, perda de peso e sinais neurológicos. O diagnóstico é feito através da associação dos sinais clínicos, exames parasitológicos, sorológicos e moleculares. Objetivou-se através deste estudo avaliar a ocorrência de infecção por E. canis em cães do município de Itabuna-Bahia, bem como identificar os fatores de risco relacionados à infecção. Para tanto, foram avaliados 405 cães provenientes do Centro de Controle de Zoonoses (CCZ), Organizações não governamentais (ONGs), cães domiciliados e semi-domiciliados da cidade de Itabuna-Bahia. Após avaliação física inicial dos cães, procedeu-se em seguida a coleta de amostras de sangue por punção venosa, para posterior extração de DNA e pesquisa de E. canis pela técnica de nested-Reação em Cadeia de Polimerase (nested-PCR). Adicionalmente, um questionário epidemiológico foi aplicado junto aos responsáveis, no qual constavam questões relacionadas aos animais, com a finalidade de identificar os fatores de risco de exposição destes ao agente etiológico e ao vetor. Em suma, este estudo mostrou que aproximadamente $17 \%$ dos cães do município de Itabuna-Bahia foram positivos para E. canis pela nested-PCR, resultado superior ao encontrado em outros estudos realizados no mesmo município. Dos fatores associados à infecção por $E$. canis, foi significativo o contato com outros cães $(\mathrm{p}=0,0226)$, um fator importante para a disseminação da EMC, pois os cães são relatados como reservatórios da $E$. canis. O gênero macho $(\mathrm{p}=0,0016)$ apresentou menor risco para a infecção por $E$. canis. Outros estudos, no entanto, descrevem que não há nenhuma associação entre o gênero do animal e a infecção por $E$. canis. Adverte-se a população sobre a necessidade de medidas profiláticas para diminuir a exposição ao vetor da erliquiose.

Palavras-chave: Canis familiaris. Ehrlichia canis. Nested-PCR. Zoonose. Doenças transmitidas por vetores.

\section{Introduçtion}

Ehrlichiosis is a zoonosis that affects many species of animals, such as domesticated animals including dogs, cats, horses, ruminants, as well as wild animals and humans (Perez, Bodor, Zhang, Xiong, \& Rikihisa, 2006; Otranto, Dantas-Torres, \& Breitschwerdt, 2009; Isola, Cardioli, \& Nakage, 2012; Vieira et al., 2013; Pritt et al., 2017). The literature describes three diseases in dogs that are caused by different species of Ehrlichia: canine monocytic ehrlichiosis, caused by Ehrlichia canis; granulocytic ehrlichiosis, caused by the agents E. ewingii e Anaplasma phagocytophilum; and thrombocytic ehrlichiosis, caused by por A. platys (Dagnone, Morais, \& Vidotto, 2001).

Canine monocytic ehrlichiosis (CME), also known as tropical canine pancytopenia, canine hemorrhagic fever, or tick typhus (Vieira et al., 2013; I. P. M. Silva, 2015), is an endemic disease in tropical and subtropical regions, with reports in temperate regions. The geographical distribution of
$\mathrm{CME}$ is related to the presence of the vector, the tick Rhipicephalus sanguineus (Vieira et al., 2013; Krawczak et al., 2015).

In Brazil, CME is present almost everywhere, since $R$. sanguineus is well adapted to tropical and subtropical regions (Accetta, 2008; Vieira et al., 2011; Ribeiro et al., 2017), with prevalence ranging from $7 \%$ to $60 \%$ (Dagnone et al., 2001; Fonseca, Hirsch, \& Guimarães, 2013; I. P. M. Silva, 2015).

CME can have three clinical stages: acute, subclinical, and chronic. In the acute stage of the disease, the dog presents with fever, depression, and anorexia. In the subclinical phase, the animal presents predominantly with hematological alterations such as thrombocytopenia, leukopenia, and anemia. In the chronic stage, the same signs as in the acute phase are present, in addition to bone marrow hypoplasia and some neurological signs such as ataxia, neuromotor dysfunction, and central or peripheral vestibular dysfunction (Morais, Hoskins, Almosny, \& Labarthe, 2004; Moretti, 
Silva, Ribeiro, Paes, \& Langoni, 2006; Saito, 2009; Isola et al., 2012; I. P. M. Silva, 2015).

The diagnosis of CME is based on clinical signs, in conjunction with the results of parasitological, serological, and molecular tests (Carvalho, Wenceslau, Carlos, \& Alburquerque, 2008). The polymerase chain reaction (PCR) enables a more accurate diagnosis of CME, with good results in both acute and chronic phase animals (Iqbal \& Rikihisa, 1994). Besides having high sensitivity and specificity, PCR allows differentiation between species of the genus Ehrlichia, unlike other diagnostic techniques. Furthermore, due to its high sensitivity, it is able to identify a small amount of parasite DNA, equivalent to only five copies of $E$. canis (Ueno et al., 2009).

The increase in the number of cases of ehrlichiosis in recent years has motivated further research, due to both the zoonotic character of this disease and the high morbidity and mortality rates in dogs (Dagnone et al., 2001; Menezes, Souza,
Teixeira, \& Guimarães, 2008; Guedes et al., 2015). Thus, the aim of the present study was to evaluate the occurrence of E. canis infection in dogs of Itabuna-Bahia, Brazil, as well as to determine the factors associated with exposure to the agent.

\section{Material and Methods}

\section{Study area and animals}

The study was conducted in the municipality of Itabuna (Latitude $14^{\circ} 47^{\prime} 08^{\prime \prime}$ South; Longitude $39^{\circ} 16^{\prime} 49^{\prime \prime}$ West), located in the Southern Bahia Region, Ilhéus-Itabuna Microregion, State of Bahia, Brazil (1). The city is about 426 kilometers from the state capital and is part of the Atlantic Forest biome. The municipality has an estimated population of $219,680,000$ inhabitants, a total area of $401,028 \mathrm{~km}^{2}$ and a population density of 473,50 inhabitants $/ \mathrm{km}^{2}$. The average rainfall is $1419 \mathrm{~mm}$ per year (Instituto Brasileiro de Geografia e Estatística [IBGE], 2016).

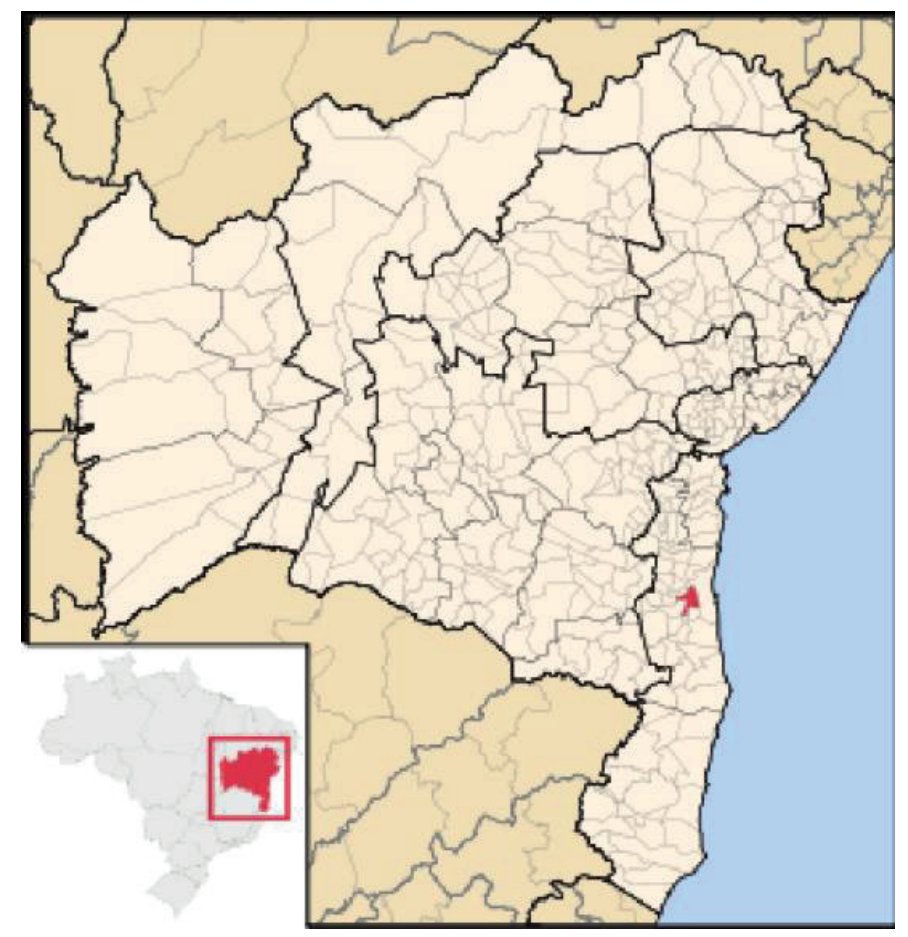

Figure 1. Location of the municipality of Itabuna in Bahia. Fonte: http://www.skyscrapercity.com/showthread.php?t=463643 
The study included 405 dogs from an estimated population of 32,839 , with age ranging from four months to 15 years, of both sexes, which were sampled for convenience. The dogs were domiciled, without free street access (162 animals), or semidomiciled, with some street access (173 animals). Some came from the Zoonosis Control Center (ZCC) (22 dogs) and non-governmental organizations (NGOs) (48 dogs).

Sample collection was performed from March to June 2016. Prior to the inclusion of the animals in the study, the owners or guardians of the dogs were informed about the research, and after agreement, signed a free and informed consent. This study was approved by the Animal Use Ethics Committee (CEUA) of the Santa Cruz State University located in the municipality of Ilhéus, southern Bahia, Brazil (Protocol 034/15).

History, clinical examination, and epidemiological data collection

An epidemiological questionnaire was administered to dog owners and/or guardians. Questions related to animals (sex, age, presence of ticks, and contact with other dogs) were asked, in order to identify the risk factors associated with infection. Anamnesis and physical examination of all dogs included in the study were performed, in which mucosa staining, hydration, lymph node size, tick parasitism, presence of petechiae, and ecchymoses in the skin and mucosa were verified, in order to investigate the occurrence of physical changes consistent with the disease.

\section{Biological samples collection}

After physical restraint, $5 \mathrm{~mL}$ of blood was collected from each dog through jugular or cephalic venipuncture using sterile syringes and needles. The samples were stored in tubes with ethylenediamine tetraacetic acid anticoagulant (EDTA) and stored in a recyclable ice pack. Subsequently, the leukocyte cap, which corresponds to the layer where most of the leukocytes and platelets are concentrated was collected via centrifugation. and separation by density gradient. The materials were then stored in Eppendorf-like tubes at $-20^{\circ} \mathrm{C}$ until DNA extraction.

\section{DNA extraction and polymerase chain reaction}

DNA was extracted from the leukocyte coat using the Easy-DNA kit (Invitrogen $\left.{ }^{\circledR}\right)$, following the manufacturer's instructions. The extracted DNA was quantified using Nanodrop and then stored at $-20{ }^{\circ} \mathrm{C}$. For E. canis DNA amplification, a nested PCR was performed. In the first reaction, forward ECC (5'-AGAACGAACGCTGGCGGCAAGC-3 ') and reverse $\mathrm{ECB}$ (5' -CGTATTACCGCGGCTGCTGGCA-3') primers were used, which amplify part of the Ehrlichia spp. 16SrRNA gene. In the second reaction, the forward ECAN '-CAATTATTTATAGCCTCTGGCTATAGGA-3') and reverse HE3 (5'TATAGGTACCGTCATTATCTTCCCTAT-3') primers were used, according to the methodology described by Murphy, Ewing, Whitworth, Fox and Kocan (1998), to give a final product of 396 base pairs.

Each reaction mixture was prepared to a final volume of $25 \mu \mathrm{L}$ and contained $0.2 \mathrm{mM}$ of each dNTP, $1.5 \mathrm{mM} \mathrm{MgCl}, 50 \mathrm{mM} \mathrm{KCl}, 10 \mathrm{mM}$ Tris$\mathrm{HCl}, \mathrm{pH}$ 9.0, $0.2 \mu \mathrm{M}$ of each primer, $2 \mathrm{U}$ TaqDNA polymerase (Invitrogen $\AA$ ), and $6 \mu \mathrm{L}$ of purified DNA. Nested-PCR reactions used $3 \mu \mathrm{L}$ of amplified products. The first reaction amplification protocol consisted of initial denaturation for 3 minutes at $94{ }^{\circ} \mathrm{C}$, followed by 35 cycles of denaturation at 94 ${ }^{\circ} \mathrm{C}$ for 1 minute, annealing at $68{ }^{\circ} \mathrm{C}$ for 2 minutes, extension at $72{ }^{\circ} \mathrm{C}$ for 2 minutes, and a final extension $72{ }^{\circ} \mathrm{C}$ for 7 minutes (Carvalho et al., 2008). For the second reaction, initial denaturation was performed for 3 minutes at $94{ }^{\circ} \mathrm{C}$, followed by 35 cycles of denaturation at $94{ }^{\circ} \mathrm{C}$ for 1 minute, annealing at $58{ }^{\circ} \mathrm{C}$ for 2 minutes, extension at $72{ }^{\circ} \mathrm{C}$ for 1.5 
minutes, with final extension at $72{ }^{\circ} \mathrm{C}$ for 7 minutes (Carvalho et al., 2008). Nested-PCR products were submitted to $1.5 \%$ agarose gel electrophoresis containing Sybrgreen (SYBR Safe DNA gel stain Invitrogen). Positive controls were samples positive for E. canis (Guedes et al., 2015). Ultrapure water was used as negative control. Bands were verified using an ultraviolet transilluminator, followed by photocumentation on the Locus Biotechnology L-Pix Transilluminator.

\section{Statistical analysis}

The analysis of the results was performed based on the association between risk factors and the results obtained in nested-PCR. The data obtained from the physical inspection of the animals were also analyzed. Data were analyzed using the Chi-square test or Fisher's exact test with the aid of Epi-Info 7.2.0.1. Bivariate analysis and then multivariate analysis were performed using unconditional logistic regression to identify risk factors related to $E$. canis infection. In the bivariate analysis, all independent variables were crossed with the dependent variables (positive or negative for E. canis), selected, and subjected to Spearman correlation to verify multicollinearity ( $p>0.8)$.

\section{Results}

Of the 405 dogs evaluated, 67 dogs (16.54\%) tested positive for E. canis. The physical changes observed in the animals are shown in Figure 2. The presence of petechiae/ecchymoses $(p=0.016)$ in the skin and mucosa was more frequent in animals positive for E. canis (Table 1). Among the factors associated with $E$. canis infection, male sex (p = 0.0016) was a factor associated with lower risk of infection, while contact with other dogs ( $\mathrm{p}=$ 0.0226) was a risk factor (Tables 2 and 3). There was no collinearity between the variables $(\mathrm{p}>0.8)$.

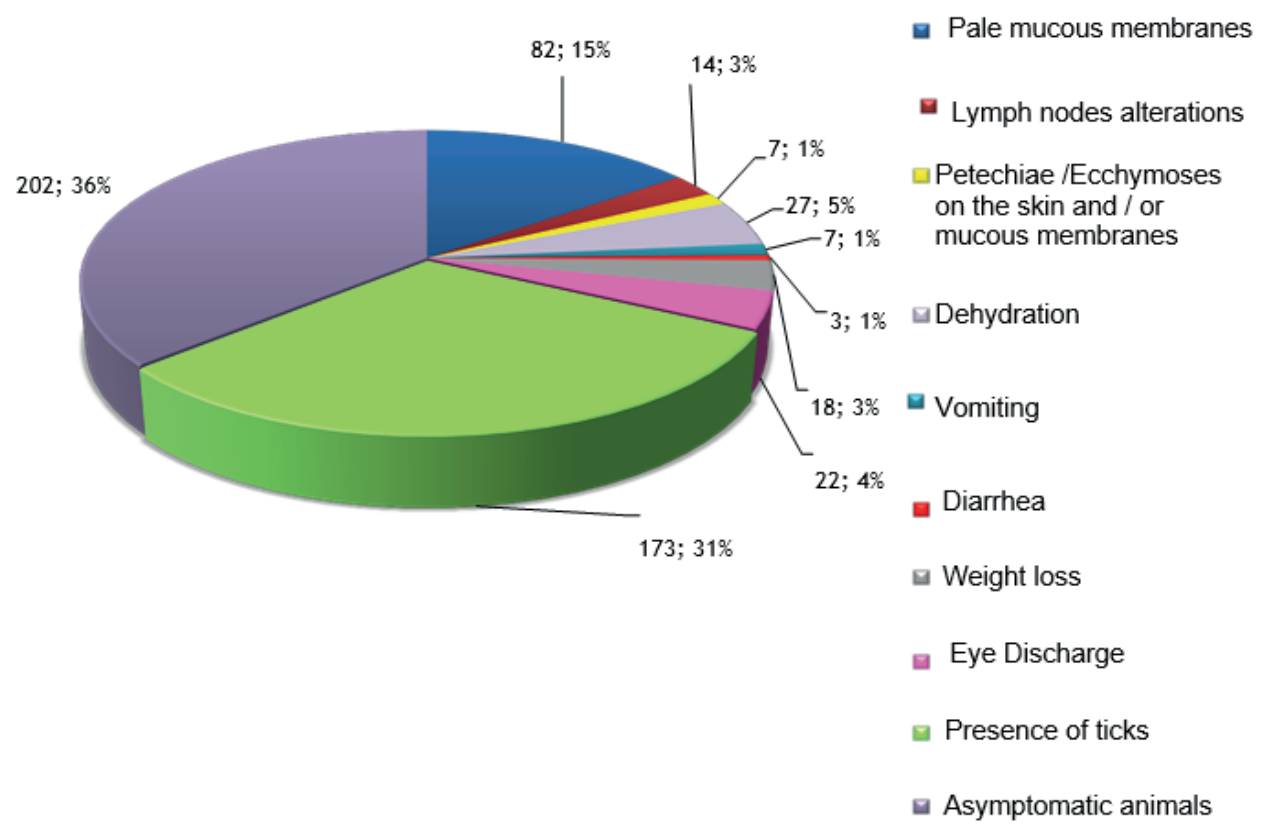

Figure 2. Physical changes consistent with ehrlichiosis presented by dogs evaluated from Itabuna-Bahia. 
Table 1

Findings observed on physical examination of dogs from the municipality of Itabuna-Bahia positive for $E$. canis in nested-PCR

\begin{tabular}{lccccccc}
\hline Variable & \multicolumn{2}{c}{$\mathrm{N}$} & Positive dogs & Prevalence & OR & $95 \%$ CI & P-value \\
\hline \multirow{2}{*}{ Pale mucous membranes } & Yes & 82 & 12 & $14,63 \%$ & 0,83 & $0,42-1,64$ & 0,72 \\
& No & 323 & 55 & $17,02 \%$ & $1^{*}$ & & \\
Lymph nodes alterations & Yes & 14 & 1 & $7,14 \%$ & 0,37 & $0,04-2,94$ & 0,55 \\
& No & 391 & 66 & $16,87 \%$ & $1^{*}$ & & \\
Petechiae/ & Yes & 7 & 4 & $57,14 \%$ & 7,08 & $1,54-32,44$ & 0,016 \\
Ecchymoses & No & 398 & 63 & $15,82 \%$ & $1^{*}$ & & \\
Dehydration & Yes & 27 & 5 & $18,51 \%$ & 1,15 & $0,42-3,17$ & 0,98 \\
& No & 378 & 62 & $16,40 \%$ & $1^{*}$ & & \\
Vomiting & Yes & 7 & 2 & $28,57 \%$ & 2,04 & $0,38-10,79$ & 0,72 \\
& No & 398 & 65 & $16,33 \%$ & $1^{*}$ & & \\
Diarrhea & Yes & 3 & 0 & - & - & - & $1,00^{* *}$ \\
\hline
\end{tabular}

*Reference

**Fisher's test.

Table 2

Bivariate analysis of the variables related to $E$. canis infection in positive dogs from Itabuna-Bahia

\begin{tabular}{lccccccc}
\hline Variable & \multicolumn{2}{c}{$\mathrm{N}$} & $\begin{array}{c}\text { Positive } \\
\text { dogs }\end{array}$ & Prevalence & OR & 95\% CI & P-value \\
\hline \multirow{2}{*}{ Tick Presence } & Yes & 173 & 29 & $16,76 \%$ & 1,02 & $0,60-1,74$ & 1,00 \\
\multirow{4}{*}{ Age (years) } & No & 232 & 38 & $16,37 \%$ & $1^{*}$ & & \\
\multirow{5}{*}{ Contact with other dogs } & $<5$ years & 272 & 46 & $16,91 \%$ & 0,98 & $0,55-1,76$ & 1,00 \\
\multirow{2}{*}{ Gender } & $>5$ years & 133 & 21 & $15,79 \%$ & $1^{*}$ & & \\
& Yes & 198 & 41 & $20,70 \%$ & 1,81 & $1,06-3,10$ & 0,038 \\
& No & 207 & 26 & $12,56 \%$ & $1^{*}$ & & \\
& Female & 213 & 47 & $22,06 \%$ & $1^{*}$ & $0,23-0,72$ & 0,003 \\
\hline
\end{tabular}

*Reference.

Table 3

Multivariate analysis of the association between dogs positive for $E$. canis and gender and contact with other dogs, in the municipality of Itabuna-Bahia

\begin{tabular}{lccc}
\hline Variable & Odds Ration & Confidence Interval 95\% & $P$-value \\
\hline Contact with other dogs & 1,88 & $1,09-3,23$ & 0,0226 \\
Male gender & 0,40 & $0,22-0,70$ & 0,0016 \\
\hline
\end{tabular}

Likelihood $=0,004$. 


\section{Discussion}

The frequency of infection found in this study was higher than that observed by Carvalho et al. (2008), who reported $7.8 \%$ prevalence of $E$. canis infection through nested-PCR using the same primers, in dogs from the cities of Ilhéus and Itabuna. This higher percentage of cases in the municipality of Itabuna verified in this study may be due to the fact that the sampling was more significant compared to that of Carvalho et al. (2008), who evaluated only 69 samples from this municipality. Other studies conducted in the state of Bahia found higher prevalence rates of $E$. canis infection. Using nestedPCR and the same primers, Menezes et al. (2008) and Guedes et al. (2015) reported $33.3 \%$ and $25.6 \%$ of positive animals in the municipalities of Salvador and Ituberá, respectively.

In addition, most of the animals evaluated came from the ZCC, NGOs, and poor neighborhoods, where a higher frequency of infection was expected, as these locations usually pose a higher risk of dog exposure to the vector tick. This greater exposure occurs due to contact with other dogs, which facilitates the acquisition of ticks, and there is usually no adequate prophylaxis such as vector tick control using acaricides, identification, and treatment of sick animals to decrease the chance of infestation. (Otranto et al., 2010). This can be reinforced by the result obtained in this study, which shows that animals that had contact with other dogs were more likely to become infected than those who did not have this type of contact (Table 3). In a study developed by Azevedo et al. (2011), contact with other dogs was also considered a risk factor for $E$. canis infection, indicating that this is an important factor for the transmission of CME.

Another factor that may influence the variation between the results is the phase of the disease in which the animal is at the moment the diagnosis is made. In the acute phase of EMC, bacteria are detected in the circulating blood, while in the subclinical or chronic phases, spleen sequestration of infected cells may occur (Faria et al., 2010; Harrus \& Waner, 2011). Thus, PCR from blood samples has better sensitivity when the animals are in the acute phase of the disease. During the physical evaluation of the dogs in this study, 202 of the 405 animals did not manifest clinical signs characteristic of CME (Figure 2), and are therefore not in the acute phase of the disease. However, 23 of these 202 animals were positive for $E$. canis, reinforcing the fact that animals infected with E. canis may have subclinical infection. Animals may remain infected for years without showing clinical signs of the disease. Some authors, however, reported the occurrence of slight hematological changes such as thrombocytopenias, in addition to high specific antibody titers (Harrus \& Waner, 2011). Immunocompetent dogs usually recover, while immunocompromised dogs progress to the chronic disease phase (I. P. M. Silva, 2015).

In this study, an association was observed between the presence of petechiae and ecchymoses in the skin and/or mucosa and E. canis infection. Saito (2009) and Witter et al. (2013) also associated the presence of these changes with infection with this agent. Generally, animals with CME have vascular disorders associated with thrombocytopenia, which cause petechial hemorrhages and bruises in different organs and body regions (Ueno et al., 2009).

The results obtained in this study indicate that males have lower risk of infection with $E$. canis. Other studies, however, reported no association between animal gender and E. canis infection (Nakaghi, Machado, Costa, André, \& Baldani, 2008; Sousa et al., 2010; Isola et al., 2012; G. C. Silva et al., 2012).

Although some studies have suggested that age and tick parasitism are risk factors for $E$. canis infection, in this study these factors had no significant effects. This lack of association has also been reported by other authors (Carlos, Carvalho, Wenceslau, Almosny, \& Albuquerque, 2011; Souza et al., 2010; Ueno et al., 2009; Witter et al., 2013). 
Regarding the absence of ticks in most positive animals at the time of collection (Table 2), it is worth noting the possibility that these dogs were parasitized by $R$. sanguineus before the examination. Although there was no statistical significance in this study, dog exposure to $R$. sanguineus is of extreme importance for the transmission of CME. Infected ticks only transmit the bacteria for a period of 155 days (Lewis Jr., Ristic, Smith, Lincoln, \& Stephenson, 1977); however, dogs can remain infected for up to five years after the initial infection (Trapp et al., 2006; Saito, 2009; Isola et al., 2012). Thus, it is necessary for the tick to become infected by performing blood repast on an infected dog and subsequently transmit the infection to a healthy dog (Saito, 2009; Guedes et al., 2015).

\section{Conclusion}

This study revealed a high prevalence of dogs positive for $E$. canis in the municipality of ItabunaBahia, Brazil. This result warns of the imminent risk of exposure of the human and canine population to this agent, which is a zoonosis and have adverse effects on public health. Veterinarians should always advise the population on the care of their animals so that exposure to R. sanguineus is reduced.

\section{Acknowledgments}

Research supported by FAPESB and UESC.

\section{References}

Accetta, E. M. T. (2008). Ehrlichia canis e Anaplasma platys em cães (Canis familiaris, Linnaeus, 1758) trombocitopênicos da região dos lagos do Rio de Janeiro. Dissertação mestrado em Medicina Veterinária, Universidade Federal Rural do Rio de Janeiro, Rio de Janeiro, RJ, Brasil.

Azevedo, S. S., Aguiar, D. M., Aquino, S. F., Orlandelli, R. C., Fernandes, A. R. F., \& Uchoa, I. C. P. (2011). Soroprevalência e fatores de risco associados à soropositividade para Ehrlichia canis em cães do semiárido da Paraíba. Brazilian Journal of Veterinary
Research and Animal Science, 48(1), 14-18. doi: 10.11606/S1413-95962011000100002

Carlos, R. S. A., Carvalho, F. S., Wenceslau, A. A., Almosny, N. R. P., \& Albuquerque, G. R. (2011). Risk factors and clinical disorders of canine ehrlichiosis in the South of Bahia, Brazil. Revista Brasileira de Parasitologia Veterinária, 20(3), 210-214. doi: 10.1590/S1984-29612011000300006

Carvalho, F. S., Wenceslau, A. A., Carlos, R. S. A., \& Albuquerque, G. R. (2008). Epidemiological and molecular study of Ehrlichia canis in dogs in Bahia, Brazil. Genetics and Molecular Research, 7(3), 657662. doi: 10.4238/vol7-3gmr468

Dagnone, A. S., Morais, H. S. A., \& Vidotto, O. (2001). Erliquiose nos animais e no homem. Semina: Ciências Agrárias, 22(2), 191-201. doi: 10.5433/1679-0359.2001v22n2p191

Faria, J. L. M., Dagnone, A. S., Munhoz, T. D., João, C. F., Pereira, W.A. B, Machado, R.Z., \& Tinucci-Costa, M. (2010). Ehrlichia canis morulae and DNA detection in whole blood and spleen aspiration samples. Revista Brasileira de Parasitologia Veterinária, 19(2), 98-102. doi: 10.4322/rbpv.01902006

Fonseca, J. P., Hirsch, C., \& Guimarães, A. M. (2013). Erliquiose monocítica canina: epidemiologia, imunopatogênese e diagnóstico. PUBVET, 7(8), 619-706. doi: 10.22256/pubvet.v7n8.1529

Guedes, P. E. B., Oliveira, T. N. A., Carvalho, F. S., Carlos, R. S. A., Albuquerque, G. R., Munhoz, A. D., \& Silva, F. L. (2015). Canine ehrlichiosis: prevalence and epidemiology in northeast Brazil. Brazilian Journal of Veterinary Parasitology, 24(2), 115-121. doi: 10.1590/S1984-29612015030

Harrus, S., \& Waner, T. (2011). Diagnosis of canine monocytotropic ehrlichiosis (Ehrlichia canis): an overview. The Veterinary Journal, 187(3), 292-296. doi: 10.1016/j.tvj1.2010.02.001

Instituto Brasileiro de Geografia e Estatística. (2016). Censo demográfico. Rio de Janeiro: IBGE. Recuperado de https://cidades.ibge.gov.br/brasil/ba/ itabuna/panorama

Isola, J. G. M. P., Cadioli, F. A., \& Nakage, A. P. (2012). Erliquiose canina-Revisão de literatura. Revista Cientifica Eletrônica de Medicina Veterinária, ANO IX(8), 1-11.

Iqbal, Z., \& Rikihisa, Y. (1994). Reisolation of Ehrlichia canis from blood and tissues of dogs after doxycycline treatment. Journal Clinical Microbiology, 32(7), 1644-1649. 
Krawczak, F. S., Reis, I. A., Silveira, J. A., Avelar, D. M., Marcelino, A. P., Werneck, G. L., \& Paz, G. F. (2015). Leishmania, Babesia and Ehrlichia in urban pet dogs: co-infection or cross-reaction in serological methods? Revista da Sociedade Brasileira de Medicina Tropical, 48(1), 64-68. doi: 10.1590/00378682-0291-2014

Lewis, G. E. Jr., Ristic, M., Smith, R. D., Lincoln, T., \& Stephenson, E. H. (1977). The brown dog tick Rhipicephalus sanguineus and the dog as experimental hosts of Ehrlichia canis. American Journal of Veterinary Research, 38(12), 1953-1955.

Menezes, S. D. I., Souza, B. M. P. S., Teixeira, C. M. M., \& Guimarães, J. E. (2008). Perfil clínico-laboratorial da erliquiose monocítica canina em cães de Salvador e região metropolitana, Bahia. Revista Brasileira Saúde Produção Animal, 9(4), 770-776.

Morais, H. A., Hoskins, J., Almosny, N. R. P., \& Labarthe, N. V. (2004). Diretrizes gerais para diagnóstico e manejo de cães infectados por Ehrlichia spp. Clínica Veterinária, 9(48), 28-30.

Moretti, L. D., Silva, A. V. da, Ribeiro, M. G., Paes, A. C., \& Langoni, H. (2006). Toxoplasma gondii genotyping in a dog co-infected with distemper vírus and ehrlichiosis rickettsia. Journal of the Institute of Tropical Medicine of São Paulo, 6(48), 359-363. doi: 10.1590/S0036-46652006000600012

Murphy, G. L., Ewing, S. A, Whitworth, L. C, Fox, J. C, \& Kocan, A. A. (1998). A molecular and serologic survey of Ehrlichia canis, E. chaffeensis, and E. ewingii in dogs and ticks from Oklahoma. Veterinary Parasitology, 79, 325-339.

Nakaghi, A. C. H., Machado, R. Z., Costa, M. T., André, M. R., \& Baldani, C. D. (2008). Canine ehrlichiosis: clinical, hematological, serological and molecular aspects. Ciência Rural, 38(3), 766-700. doi: 10.1590/ S0103-84782008000300027

Otranto, D., Dantas-Torres, F., \& Breitschwerdt, E. B. (2009). Managing canine vector-borne diseases of zoonotic concern: parte one. Trends in Parasitology, 25(4), 157-163. doi: 10.1016/j.pt2009.01.003

Otranto, D., Caprariis, D. de, Lia, R. P., Tarallo, V., Lorusso, V., Testini, L., \& Stanneck, D. (2010). Prevention of endemic canine vector-borne diseases using imidacloprid $10 \%$ and permethrin $50 \%$ in young dogs: a longitudinal field study. Veterinary Parasitology, 172(3-4), 323-32. doi: 10.1016/j. vetpar.2010.05.017

Perez, M., Bodor, M., Zhang, C., Xiong, Q., \& Rikihisa, Y. (2006). Human infection with Ehrlichia canis accompanied by clinical signs in Venezuela. Annals New York Academy of Sciences, 1078(1), 110-117. doi: 10.1196/annals.1374.016

Pritt, B. S., Allerdice, M. E. J., Sloan, L. M., Paddock, C. D., Munderloh, U. G., Rikihisa, Y., \& Karpathy, S. E. (2017). Proposal to reclassify Ehrlichia muris as Ehrlichia muris subsp. muris subsp. nov. and description of Ehrlichia muris subsp. eauclairensis subsp. nov., a newly recognized tick-borne pathogen of humans. International Journal of Systematic and Evolutionary Microbiology, 67(7), 2121-2126. doi: 10.1099/ijsem.0.001896

Ribeiro, C. M., Matos, A. C., Azzolini, T., Bones, E. R., Wasnieski, E. A., Richinipereira, V. B, \& Vidotto, O. (2017). Molecular epidemiology of Anaplasma platys, Ehrlichia canis and Babesia vogeli in stray dogs in Paraná, Brazil. Pesquisa Veterinária Brasileira, 37(2), 129-136. doi: 10.1590/S0100736X2017000200006

Saito, T. B. (2009). Estudo da erliquiose em cães expostos a carrapatos Rhipicephalus sanguineus experimentalmente infectados. Tese doutorado em Medicina Veterinária, Universidade de São Paulo, São Paulo, SP, Brasil. doi: 10.11606/T.10.2009.tde20022009-134729

Silva, G. C., Benitez A. N., Girotto, A., Taroda, A., Vidotto, M. C., Garcia, J. L., \& Vidotto, O. (2012). Occurrence of Ehrlichia canis and Anaplasma platys in household dogs from northern Parana. Revista Brasileira de Parasitologia Veterinária, 21(4), 379385. doi: 10.1590/S1984-29612012005000009

Silva, I. P. M. (2015). Erliquiose canina - revisão de literatura. Revista Cientifica de Medicina Veterinária, Ano XIII (24), 1-16.

Sousa, V. R. F., Almeida, A. B. P. F., Barros, L. A., Sales, K. G., Justino, C. H. S., Dalcin, L., \& Bomfim, T. C. B. (2010). Avaliação clínica e molecular de cães com erliquiose. Ciência Rural, 40(6), 1309-1313. doi: 10.1590/S0103-84782010000600011

Trapp, S. M., Dagnone, A. S., Vidotto, O., Freire, R. L., Amude, A. M., \& Morais, H. S. de. (2006). Soroepidemiologia da babesiose canina e erliquiose em população hospitalar. Veterinary Parasitology, 140(3-4), 223-230. doi: 10.1016/j.vetpar.2006.03.030

Ueno, T.E.H.,Aguiar, D. M., Pacheco, R. C., Richtzenhain, J., Ribeiro, M. G., Paes, \& Labruna, M. B. (2009). Ehrlichia canis em cães atendidos em hospital veterinário de Botucatu, Estado de São Paulo, Brasil. Revista Brasileira de Parasitologia Veterinária, 18(3), 57-61. doi: 10.4322/rbpv.01803010 
Vieira, R. F. C., Biondo, A. W., Guimarães, A. M. S., Santos, A. P., Santos, R. P., Dutra, L. H., \& Vidotto, O. (2011). Ehrlichiosis in Brazil. Revista Brasileira de Parasitologia Veterinária, 20(1), 1-12. doi: 10.1590/S1984-29612011000100002

Vieira, R. F. C., Vieira, T. S. W. J., Nascimento, D. A. G., Martins, T. F., Krawczak, F. S., Labruna, M. B., \& Vidotto, O. (2013). Serological survey of Ehrlichia species in dogs, horses, and humans: Zoonotic scenery in a rural settlement from southern Brazil. Revista do Instituto de Medicina Tropical, 5(55), 335-40. doi: 10.1590/S0036-46652013000500007
Witter, R., Vecchi, S. N., Pacheco, T. A., Melo, A. L. T., Borsa, A., Sinkoc, A. L., \& Aguiar, D. M. (2013). Prevalência da erliquiose monocítica canina e anaplasmose trombocítica em cães suspeitos de hemoparasitose em Cuiabá, Mato Grosso. Semina: Ciências Agrárias, 34(6), p. 3811-3822. doi: 10.5433/1679-0359.2013v34n6Sup12p3811 